\title{
Choline Transporter-Like Protein 1
}

National Cancer Institute

\section{Source}

National Cancer Institute. Choline Transporter-Like Protein 1. NCI Thesaurus. Code C112083.

Choline transporter-like protein 1 (657 aa, 73 kDa) is encoded by the human SLC44A1 gene. This protein plays a role in choline transport. 